\title{
3 Conflicts
}

\subsection{A Culture of Conflict}

Antagonistic interaction between users goes back to the beginning of the Internet, and the negative effect of anonymity in the "global village" has been a prominent recurring theme in research about computer-mediated communication (CMC). Interaction on Facebook and YouTube is further complicated by social and economic pressures, which push users toward more engaging, controversial content to garner more views. Users like Joshua Feuerstein, theamazingatheist, and John Fontain are spokespeople for ideological positions and also entertainers, whose online personalities are developed to attract more viewers. For the theamazingatheist, this includes a performance of anger, creating conflict which may or may not be genuine, but which generates controversy and more engagement with his videos. Why users get drawn into ongoing "drama" and what effect it has on interreligious dialogue are also not simple questions to answer. In this chapter, I will look specifically at the conflict that is at the center of the interaction among Feuerstein, Fontain, and theamazingatheist and show how it provides users with the affordance to take positions in relation to others.

Antagonism in computer-mediated communication can be traced back to the 1980s (Kiesler et al., 1984; Siegel et al., 1986), with research focused on how communicating through computer technology led to deindividuation, or a sense of anonymity. As research into online interaction developed, a description of negative behavior online as "flaming" emerged. Flaming has been described as the sending of aggressive individual messages "related to a specific topic and directed at an individual user" (Crystal, 2001, p. 55) or "scathingly critical personal messages" (Cosentino, 1994) or "rude or insulting messages" (Schrage, 1997). Brown and Levinson's (1987) notion of a "facethreatening act" has influenced the development of descriptions of online impoliteness (and impoliteness more generally), with notions of categorizing different kinds of "flames" (O'Sullivan and Flanagin, 2003). With the rise of mobile technologies, and the embedded nature of the Internet in everyday life, the questions around how and why conflict arises online has become a much 
more diverse and complex question. While "flaming" was sufficient in some way to describe responses to emails or other text-based messaging services, it doesn't encompass the range of negative interactions that can be present in all the different contexts we might consider. The same could be said of "trolling," which Hardaker (2010) has attempted to classify, with some frustration for the imprecision with which these words are often used in online contexts. They are often neologisms or metaphors that are by their very nature vague. What one does when one "trolls" another user might have some consistency in patterns of usage, or it might differ greatly, depending on the context and the particular action being described.

Research into impoliteness online has, understandably, been interested in describing larger trends in interaction on the Internet and explaining what motivates negative behavior online. There has also been interesting research into how politeness norms are managed as in online fora (Angouri and Tseliga, 2010), online communities (Nishimura, 2010; Planchenault, 2010), and interaction such email discussion lists (Haugh, 2010; Luchjenbroers and AldridgeWaddon, 2011). While this research has focused on the effects of technology on the negotiation and understanding of politeness norms in online settings, they have also been primarily studies in asynchronous, text-based interaction. This is reflective of the development of technology, in which text-based interaction has remained a dominant form of CMC (Tagg, 2012; Seargeant and Tagg, 2014).

As technology has developed, there was a sense that part of the reason antagonism existed online was that people were only interacting in a written mode rather than exposing themselves visually (Lange, 2007a). If, as Kiesler and colleagues (1984) initially suggested, part of the reason for antagonism and negativity stemmed from other users being displaced and distant, then technology which allowed for a more multimodal experience of others may reduce the amount of negativity that users experience. YouTube, with its multimodal video page and ability to respond to others "face-to-face" had the potential to reduce the amount of negativity. This has largely not been the case, although it is difficult to judge what aspects of the experience on YouTube lead to negativity. YouTube remains well known for its negativity, particularly the comments section which despite the integration with Google's social networking application Google+ are often anonymous. My own work (Philaja, 2014a) has looked at the ways in negativity is also present in the making of "drama videos," where users seem willing to often speak out loud and with their face on camera many of the negative things that they might otherwise type.

The nature of YouTube celebrity and the pressure to "get views" might be partially responsible for the popularity of drama videos, since users in my data sets have regularly referred to the interest they generate. The early research of 
Lange (2006, 2007b, 2007a), and Moor and colleagues (2010) focused on the experience of YouTubers on the site and how users understood things like "flaming" in comments, finding that in some ways, the negativity and ongoing drama was part of the interest of the site, with users seeking out content that includes conflict for its entertainment value. Facebook does not suffer from the same reputation of negativity as YouTube, in part due to the lack of anonymity of users who often know their Facebook friends from "real-world" settings and a focus at least initially on status updates, which encourage narrativity and shared experience with friends (Page, 2010). The site, however, is not entirely free of negativity, and Phillips (2011), for example, has studied the emergence of trolling on Facebook memorial sites. Troubling as well is the use of Facebook for bullying, which Kwan and colleagues (2013) have also investigated, showing that Facebook bullying can become an extension of offline school bullying. This research shows how Facebook can represent a clearer link between online and offline realities, differing from YouTube comments on video pages, where users are often not likely to have any offline interaction.

Research has been focused on particular moments of negative reactions around specific topics or videos, like analyzing rape threats against feminist campaigner Caroline Criado-Perez (Hardaker and McGlashan, 2016) or responses to the anti-Islam film Fitna (van Zoonen, Vis, and Mihelj, 2010, 2011; Vis, van Zoonen, and Mihelj, 2011) or comments on a single particular video, like the "Obama Reggaeton" YouTube video (Lorenzo-Dus et al., 2011). Less work, however, has been done on tracing how impoliteness and antagonism occur over sustained periods of times in particular communities, with a qualitative focus on the back-and-forth nature of Internet "drama," the "ongoing antagonistic debates" (Burgess and Green, 2008) that crop up regularly on social media. My own research (Pihlaja, 2011, 2014a) has focused on how understanding the nuance of particular arguments shows that there is often an important social history behind each interaction. Although different patterns and strategies for impoliteness might be observed, why they happen in each individual case is often quite complicated.

Apart from the negative role that conflict plays in the interaction among users, it can also be seen as a means of producing content. Conflict provides users with positions of opposition to "enemies," a view researchers have long held about YouTube antagonism and a historical role of argumentation (Billig, 1996) - by allowing users to take positions opposing others and present their case for their own positions and beliefs, in contrast to other users holding different positions. Argumentation is fundamentally a part of religious tradition as well, something Billig (1996) shows in his discussion of Talmudic arguments in Jewish traditions and I have shown in my own research on arguments on YouTube (Pihlaja, 2013a, 2016b). In addition to these larger 
issues, conflict can also be rooted in more mundane social interaction frustrations, like being insulted by someone, which are not rooted in deep theological or philosophical differences, but are simply the result of humans interacting with one another in a social space.

For religious talk online, what conflict does in the interaction and how it affects the relationships between people of different faiths or no faith is particularly important. When arguments do occur, they must be placed in a long history of contact between Christians and Muslims and a contemporary context of the emergence of atheism. The users exist within histories and Christian polemics about Islam (Goddard, 2000; Lewis, 1993) and atheism (Wilson, 2007; Zacharias, 2008), and the responses to these polemics are key parts of the ways people come to interact in new settings. The following analysis shows how these theological arguments are remade in online contexts and what the medium's effect is on the presentation of belief.

\title{
3.2 Positioning and Attacking
}

theamazingatheist has made videos calling out Christians for many years, but his first engagement with Joshua Feuerstein appeared in a video entitled, "Christian 'Disproves' Evolution?" posted on June 2, 2014. In the video, theamazingatheist responds to Feuerstein's video Dear Mr. Atheist by offering an explanation of evolution and arguing against and mocking Feuerstein. Dear Mr. Atheist was originally posted on Feuerstein's Facebook page and theamazingatheist used clips from the video in his response to Feuerstein. The clips show Feuerstein making an argument against evolution by claiming evolution is "not science." He says,

\author{
hey guys \\ Josh Feuerstein here \\ you know the other day I had an atheist tell me \\ that I was \\ an idiot moronic and stupid \\ for believing in God \\ that He created this world because it took \\ way too much \\ faith to believe in a process like that while \\ he believed in what he called the \\ science \\ of evolution \\ well let's go ahead and \\ let's do this \\ dear mister atheist \\ first of all
}


let me correct you

because

evolution is not a science

never has

and never will be

why?

because it cannot fit

within the parameters and parentheses of science

for one simple reason

it was never observed

(2014.06.02 AA Video) $)^{1}$

In this extract, Feuerstein presents his video as a response to an attack and positions himself as challenging an atheist user who has called him "an idiot, moronic and stupid" for his beliefs. This response is necessary, Feuerstein claims, to correct the misconceptions about himself and his faith and reassert what he sees at the truth. Feuerstein says, "Well, okay, let's do this," suggesting that he has some hesitation in making the video, but that the attack has left him with no choice. In Feuerstein's argument against evolution, there is little in-depth understanding of evolutionary biology represented. Instead, "science" as a concept is used to stage an argument for Christian belief. Feuerstein says to the generic atheist, "Let me correct you." However, the "correction" is based on a very basic understanding of evolution, reasserting claims that theamazingatheist has already challenged, particularly Feuerstein's focus on "chance" in his description of evolution.

The extent to which Feuerstein is aware that his own position is built on a disputable generalization is difficult to tell. Feuerstein does not engage in a back-and-forth dialogue with anyone on the specifics of what he says and does not respond to detractors in his comments or the comments of theamazingatheist's video. The main focus instead is a storyline about the world wherein God plans, designs, and exerts control over nature, something that becomes increasingly important considering Feuerstein's focus on presenting his own belief as true and accurate. What any user says in response is ultimately irrelevant because it can't challenge the fundamental truth of the Bible, a point Feuerstein regularly makes. He states at one point in reference to the Bible and how different people might have different interpretations: "It doesn't matter what you think" (2014.8.28 JF Video).

The positioning of himself as being attacked by atheists also provides justification for taking a stance against atheism, because he is defending himself and the truth, rather than aggressively pushing his own beliefs on

${ }^{1}$ Citations for videos are as follows: Year-Month-Day User. AA=theamazingatheist, JF=Joshua Feuerstein, JFo=John Fontain. The full list of videos can be found in the Appendix. All transcripts are represented using intonation units. 
others. Instead, he is "correcting" what he states is a false claim. For Feuerstein, the unnamed atheist who called him an idiot is responsible for the response. By speaking in categorical terms, referring to "an atheist" rather than a specific person, the encounter can be presented as exemplar of a larger storyline that is scalable on several levels. Feuerstein is not simply positioning himself as being attacked at one point by a single atheist. He is positioning himself as someone who is regularly attacked for what he believes. This is a particular interaction with a particular atheist, but the conversation is one that he presents himself as regularly having and one that is indicative of a larger argument between Christians and atheists about evolution.

For theamazingatheist, Feuerstein and Christians like him provide a platform for attacking Christian belief as illogical and incoherent. theamazingatheist, like Feuerstein, positions himself as playing defense, responding to the Dear Mr. Atheist video with a video titled Christian "Disproves" Evolution? (2014.06.02 AA Video). theamazingatheist plays Feuerstein's argument back and responds to it, playfully quoting Feuerstein and parodying his voice:

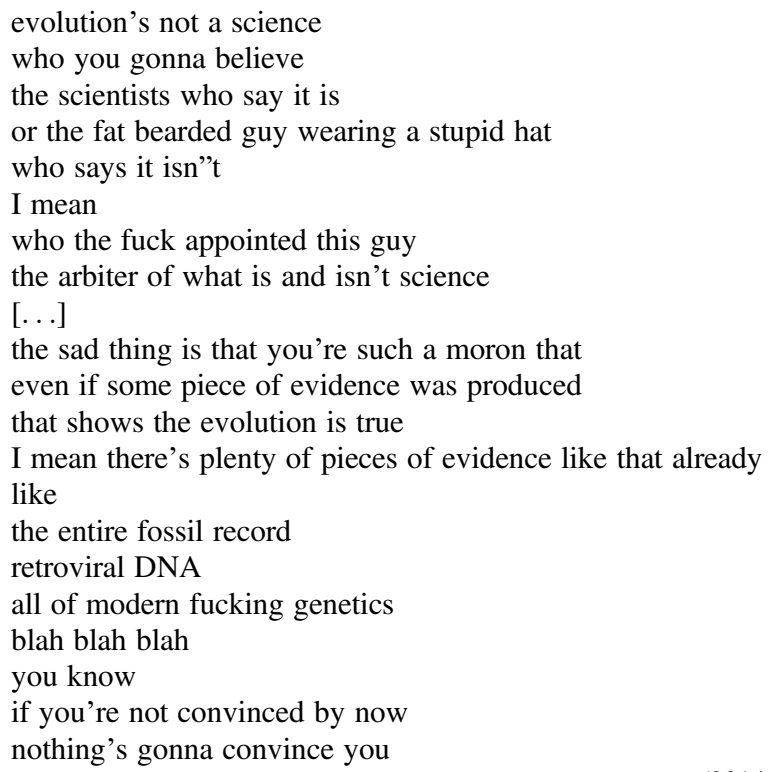

(2014.06.02 AA Video)

theamazingatheist emphasizes Feuerstein's ignorance about science, positioning Feuerstein as being completely untrustworthy as a source. Importantly, theamazingatheist does this without addressing the claim "evolution's not a science," which is what Feuerstein originally stated. The argument is positioned as completely unworthy of a response. Instead, theamazingatheist 
attacks Feuerstein with personal insults, calling him a "moron" and reducing him to a "fat bearded guy wearing a stupid hat." theamazingatheist's response to Feuerstein also positions Feuerstein as disingenuous and not arguing in good faith, especially in his treatment of "evidence." This is, based on what I have shown so far, true in some sense. Feuerstein is not interested in engaging in a meaningful dialogue about evolution. The premise of dialogue, of addressing "Mr. Atheist" or theamazingatheist specifically, is simply a rhetorical device to present himself as engaged with the opposing point of view.

The notion that Feuerstein is arguing in bad faith is key to theamazingatheist's negative portrayal of Feuerstein and provides some protection from criticism that theamazingatheist is treating Feuerstein unfairly. theamazingatheist positions Feuerstein as uninterested in dialogue and acting as a demagogue which, in turn, allows theamazingatheist to treat him without respect. Despite this explicit dismissal of the Feuerstein as a reliable source, theamazingatheist does engage Feuerstein's argument, addressing it in pointby-point commentary. He continually returns to the idea that Feuerstein is completely unreliable as a source and everyone who accepts the video is equally foolish. theamazingatheist says:

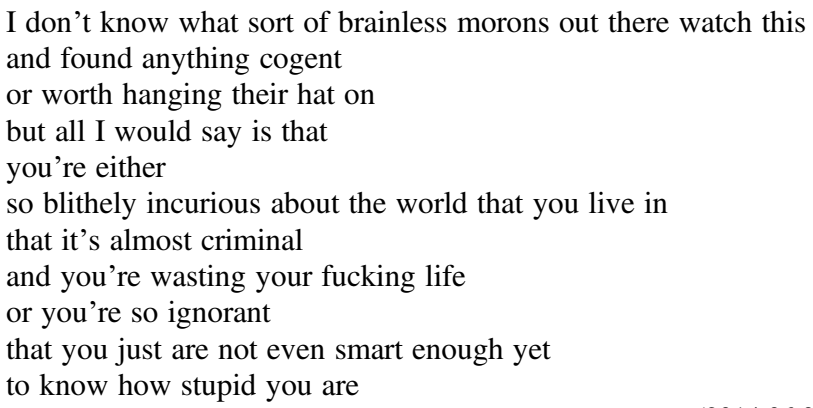

In this section of the video, theamazingatheist moves beyond attacking Feuerstein for his claims and ignorance about science and positions everyone who agrees with Feuerstein as "brainless," "ignorant," and "wasting your fucking life." This move to group Feuerstein and his viewers together serves an important function for theamazingatheist by allowing him to position Feuerstein as a kind of prototypical Christian, one who represents the beliefs of a large group of people. While theamazingatheist doesn't explicitly refer to this group of people as "Christians," there is an implicit linking between Feuerstein's rhetoric and Christianity, starting with theamazingatheist's joke that he is happy arguing with Feuerstein because he hates "arguing with Christians who are more attractive than me" (2014.06.02 AA Video). 
theamazingatheist continues this mocking of Feuerstein and positioning him and his audience as ignorant throughout the whole of the data set, including making parodies as "Josh Moronstein" in a video entitled, Gravity Disproved In 2 Minutes. The video is shot in portrait mode like Feuerstein's Facebook videos and theamazingatheist wears a red baseball cap, both references to Feuerstein's video style. In the video, Moronstein goes outside with a helium filled balloon to prove that gravity doesn't exist. The video ends with Moronstein letting the balloon float away, declaring that he disproved gravity and that he is "the smartest person on the planet." This negative positioning of Feuerstein and his audience as "morons" and "blithely incurious" and "ignorant" suggests that theamazingatheist is not attempting to convince Feuerstein that his positions are wrong. The video is not an overt outreach to Christians in Feuerstein's audience or attempt to convert them. Instead, theamazingatheist is positioning Feuerstein as an "idiot" to support his own storyline. theamazingatheist and those who agree with him are positioned as intelligent and reasonable, while Feuerstein and other Christians like him are unreasonable and illiterate about key points in science.

While theamazingatheist doesn't explicitly encourage attacks on Feuerstein, users do follow his lead. The responses to the videos in the comments revoice the same arguments against Feuerstein in a show support for theamazingatheist. I will go into more depth looking at the theme of "logic" and "stupidity" in the subsequent chapters, but for now it's useful to see the effect of theamazingatheist's attack on the subsequent responses to Feuerstein in the comments. The words "idiot," "moron," and "ignorant" appear 189, 59, and 145 times respectively in an extended discussion about the merits of intelligent design in the comments of Christian 'Disproves' Evolution?:

Joshua Loserstein makes the human race fail. His ignorant banter is stunting intellectual growth in our nation. What a shame. (2014.06.02 AA Video Comments)

this guy is a fucking idiot. $\mathrm{i}$ hate that ppl believe in his bs (2014.06.02 AA Video Comments)

Looked up Law of thermodynamics (cuz I don't claim to know everything) and the Christian dude is an idiot. Then. .......the sun goes up!!!!!!!!hahahahahahah I'm dying right now LOL (2014.06.02 AA Video Comments) ${ }^{2}$

The comments follow the same thematic elements as the video, that Feuerstein is an "idiot" and "ignorant," and extend theamazingatheist's play on Feuerstein's name, calling him "Loserstein." More important, users follow theamazingatheist's lead in extending this positioning to other groups in each of the comments, although who is grouped together with Feuerstein is different

\footnotetext{
2 All comments are presented as they appeared on the video page.
} 
depending on the commenter, with the extension applied to the "nation" (because Feuerstein's "banter is stunting intellectual growth"), "ppl (who) believe in his bs," and "Christians" (as Feuerstein is a "Christian dude"). While the linking of Feuerstein to Christian belief might be expected, Christian belief which Feuerstein represents is also tied to a larger "American Christian" identity, which is also linked to anti-intellectualism seen in the comment: "great video mate gotta love the American Christians, that special blend of dumb and dumber is just perfect" (2014.06.02 AA Video Comments). This comment suggests a larger storyline in which "American Christians" are known for lacking intelligence.

Sabat's (2003) notion of "malignant positioning" (see pg. 74) describes the process in which the person positioned in discourse has certain rights deleted as a result of the positioning. The positioning of Feuerstein as an idiot does, it appears, have the effect for some viewers at least of removing Feuerstein's right to be heard. Some users do challenge theamazingatheist's positioning of Feuerstein, but for the users that accept it, there is no consideration of the points that Feuerstein has made. Instead, a revoicing of the arguments made by theamazingatheist in the video can be seen both in the comments of theamazingatheist's videos and on Feuerstein's page. theamazingatheist seems to suggest that Feuerstein is simply an idiot and incapable of presenting any logical argument for intelligent design. Moreover, the spread of the positioning to both a religious and national category creates a more complex conflict, one that is both theological and political, and highlights the intersectionality of identity in the YouTube context, where Feuerstein's ignorance is attributed not only to his theological positions, but also his nationality.

In Dear Mr. Atheist, however, Feuerstein doesn't attempt to challenge atheist positionings of him as "idiot" by showing how his position is the result of study and research. Instead, he argues that the atheist position is even more unreasonable, repeatedly referring to evolution as requiring faith to accept. Feuerstein's positioning of himself and of the generic atheists that he is addressing accepts the notion that believing something without evidence is illogical, and at least rhetorically, downplaying the importance of faith in accepting or not accepting something at true. Instead, Feuerstein attempts to position the assumed atheist "belief" in evolution as requiring more faith than Creationism.

\author{
you see \\ you think it takes a lot of \\ of faith for me to believe in a god that created this world \\ a god that created order and yet \\ what if I were to tell you \\ that \\ somewhere in Oklahoma a tornado
}


rolls through a junk yard full of old cars and and somewhere on the other side of that tornado out of that junk pile it magically produces a perfectly red shiny working Lamborghini you would tell me I was nuts you would tell me that I had lost it you would probably try to admit me into the psychiatric ward why

because that is absolutely stupid I mean

how much faith would it really take to believe

something as idiotic as that

and yet

that's exactly what science believes

(2014.06.02 AA Video)

The story that Feuerstein tells counters a positioning of Christianity as "idiotic" - "science" instead is positioned as something "idiotic." Feuerstein represents evolution as the belief that something ordered emerged out of something disordered, using the analogy of a tornado coming through a junkyard and producing a fully formed car. This story which Feuerstein tells is also not an original story, but rather a retelling of a common story in which manufactured items like cars or watches are used to illustrate the so-called theory of Intelligent Design, which claims that an intelligent agent must be behind the creation of the universe (Dembski, 2002) and is regularly refuted by biologists (Dawkins, 1986). The use of the story represents revoicing of an argument that is not Feuerstein's own, but one that he revoices for his own purposes, including elements like "Oklahoma" and "a shiny red working Lamborghini" that are unique to this particular telling. Their purpose, as they are in other tellings of the story, is to position the person who accepts a world without a designer as, Feuerstein states, "nuts."

This positioning of "atheists" as "nuts" and people who have "lost it" in the context of religious talk online is in an implicit response to the criticism of atheists of religious individuals as "moronic and stupid." Feuerstein's response doesn't detail how faith is intelligent, but to instead challenges the intelligence of the atheists, arguing a binary position: that atheists are in fact unintelligent. This positioning of "science" as being "idiotic" or "stupid" challenges the storyline that Feuerstein initially presents of being called an "idiot" for his belief. Implicit in this claim is an acceptance that belief must be supported by evidence, but what he agrees should or should not count at evidence is an important distinction with the "atheists" he claims to be addressing.

Claims and counterclaims - logoi and anti-logoi in Billig's (1996) terminology - are important parts of argumentation, and they are embedded in the positionings and responses to being positioned. Feuerstein's response to being called ignorant is to respond by positioning theamazingatheist as ignorant; his 
response to being told he is too dependent on his faith is to position atheists as having even more faith than he does. The arguments are not necessarily nuanced or critical but points and counterpoints that do little to move the argument forward. They establish and reestablish existing storylines always needing to be retold and recast when they are challenged. If Feuerstein has been challenged as having an unfounded faith, the response is to then argue that theamazingatheist has an even more unfounded faith.

Feuerstein's approach to the generic atheist and the lack of nuance in his discussion of evolution can be explained in part by the relationship between Feuerstein and his audience. While the video is addressed to "Mr. Atheist," Feuerstein's fans on his Facebook page are primarily Christian and supportive of his message. Comments show the extent to which Feuerstein's message is approved of, with the word "Amen" appearing 1,368 times. If the primary audience of the video is then not atheists, the specifics of the argument about evolution are less important than responding to the argument that belief is stupid. In Feuerstein's storyline, everyone believes something, and Christian belief is more rational than belief in evolution. At the same time, Feuerstein doesn't, explicitly apply to scripture for his argument, but instead to a notion of common sense and his own personal experience:

it had to be by intelligent

design

so dear mister atheist

who really has to have a lot of faith today

to believe in their theory

I believe in God because I've experienced him

I've felt him

(2014.06.02 AA Video)

Here, belief is the result of personal experience and Feuerstein positions himself as not simply relying on faith, but on the evidence of his own experience and his "feeling" of God. This "feeling" and "experience" of God plays an important rhetorical role in Evangelical discourse about a "personal relationship" with God (Packer, 1973), one that is foundational to descriptions of salvation. Feuerstein speaks in a way that appeals specifically to Christians who believe God can be "experienced" and "felt," but the argument is one unlikely to sway an atheist audience. Because Feuerstein doesn't make any explicit effort to offer a more careful rebuttal of the arguments against his understanding of evolution, his positioning of himself in relation to atheists appears focused on a Christian audience. The argument does not appear to be about creating a genuine dialogue or debate about science but reasserting his position.

Ultimately, being attacked by theamazingatheist is beneficial for Feuerstein, particularly given the vicious way theamazingatheist refers to Feuerstein's beliefs and his audience. By attacking Feuerstein and everyone around him, 
theamazingatheist can be positioned as an enemy of God and the truth, a positioning that users who already have a belief about the Bible and are predisposed to Feuerstein's argument will accept. Although Feuerstein doesn't explicitly say he is being persecuted for his belief, by saying he is being "attacked" for "his belief in God," any negativity that comes his way, particularly from atheists, can be explained as persecution. A commenter on his page explicitly states this, writing in response to a post Feuerstein makes calling out "haters,"

Jesus said if they hated Me, they will hate you, don't be surprised when you face opposition and persecution. I believe that when you begin to stir up trouble for the devil he will react and respond with much rage, and just like God uses people, so does the devil. Keep the faith!!

Throughout the Facebook comments on Feuerstein's videos this theme of persecution emerges, with users referring to others who attack them as persecuting them. At least one user makes explicit reference to Bible passages that refer to persecution, particularly Matthew 5:11 (NIV) in which Jesus explicitly promises persecution to his followers, and says, "Blessed are you when people insult you, persecute you and falsely say all kinds of evil against you because of me." For Christian users, being insulted and ridiculed by others provides a kind of social capital in the Christian community because it is evidence that they are, in some way, doing what God has called them to do. theamazingatheist makes clear that he is not attacking Feuerstein for his belief in God, but rather his ignorance about science, but the explicit reason for the "persecution" seems to be less relevant than whether or not it can be positioned as the result of a belief in God.

While the atheists attacking Feuerstein is useful for the storyline of persecution, for theamazingatheist, Feuerstein is also a useful character, an issue that he explicitly addresses in his July 28, 2014 video, "The Amazing Atheist vs. Josh Feuerstein," responding to Feuerstein's sign off that includes the phrase "I love you."

\author{
I love you because thus far \\ I have made a lot of fuckin' money \\ off of responding to your videos \\ and off of pretending to be \\ Josh Moronstein \\ the character based on you \\ so I have to thank you for just supplying me \\ with tons of material \\ it's been very \\ very beneficial to me \\ and I very much appreciate it \\ and actually
}


the great thing about this is

after I make this reaction video

I can go ahead and make

an amazing atheist

uh

I can make a-a Josh Moronstein

parody of this video

so I get a double-dip

(2014.07.28 AA Video)

theamazingatheist makes the point that people like Feuerstein provide him with content, allowing him to make more money from responses. Implicitly, however, Feuerstein is also useful to theamazingatheist because Feuerstein fits into a larger storyline about Christians - they are ignorant and ill-informed and flagrant in this ignorance. Having this kind of Christian in the public eye serves the purposes of theamazingatheist by giving him an easy target to criticize. Feuerstein can be roundly rejected and ridiculed by the community, much to everyone's amusement, without having to argue against more challenging users who might be both more talented in debating and who might have a better understanding of evolutionary science. These opponents would likely be less interesting and result in far less entertaining content.

Insults also focused on the physical appearance of the users; for Feuerstein and theamazingatheist, their weight is constantly an issue. Commenters write, "We gonna believe the fat guy with a neckbeard ... or the scientist?" in relation to Feuerstein and "It's hilarious to see a fat neckbearded atheistic fedorafaggot thinking he's intellectually superior" in relation to theamazingatheist. The proliferation of negative comments - the word "fat" occurs 572 times in the comments on theamazingatheist videos - suggests that this sort of attack is normalized on the site, something to be expected and a part of the culture of the site (Moor et al., 2010; Lange, 2007a; Pihlaja, 2014a). When it becomes a part of talk about religion and religious belief, they too become a resource in mocking and insulting others.

Insults related to appearance are less frequent on the Facebook pages, with only 26 uses of the word "fat" in the Feuerstein comment corpus, and nine uses concentrated in the following exchange:

User 1: Shut the fuck up with your fat ass. Stop putting the camera so close onto your fat ass face.

User 2: I always find it funny when people call him fat. Do you really think it phases him? Well it doesn't. To even post something of this nature screams self image issue User 1: Firstly I'm pretty sure I'm not a fat bitch, secondly I'm pretty sure it does phase him that people call him fat. (2014.08.29 JF Video Comments)

This exchange provides a clear example of how insults can be perceived as unsuccessful, with the second user making the point that Feuerstein is likely 
"unphased" by the criticism and suggesting that the comment reflects poorly on the first user rather than on Feuerstein. This sense of expectation of insults without users responding explicitly to the "haters" is an important part of the ethos of the community. The negative comments serve as evidence of Feuerstein's effectiveness, with one user commenting, "The fact that you have so many haters Josh just proved you are doing something right! If you were on here spewing liberal propaganda then no one would have a problem with what you were saying." These comments seem distinctly different than more serious "trolling" involving rape or other threats of violence (Hardaker and McGlashan, 2016).

Feuerstein's own physical representation of himself is also used to attack him. Throughout the responses to Feuerstein, there are also a number of different photo comments, often taking the form of a "meme" image, with a recognizable image and text overlaid on the image. Some images employ screenshots from Feuerstein's videos to mock him. One comment with the text "More stupidity from this doofus" includes an unflattering image of Feuerstein with his mouth open and the caption "Believes in talking snakes; Thinks evolution is just silly." Another image shows Feuerstein's head photoshopped onto the naked torso of a morbidly obese man, with the caption, "Dear Mr. Atheist ... Allow me to destroy this cake in 3 seconds." Although the comments are not explicitly from users who affiliate with theamazingatheist, the tone and content which are similar to theamazingatheist's attacks suggest the success of a malignant positioning of Feuerstein, one that persists beyond theamazingatheist's video page and follows him onto his own page.

While both theamazingatheist and Feuerstein appear to be speaking to users with whom they share beliefs, the effect of their videos is worth considering particularly in terms of "converting" Christians away from their faith. For example, the research suggests that the presence of atheistic voices online are influential in encouraging people to come out as an atheist (Cimino and Smith, 2011; Smith and Cimino, 2012). Although theamazingatheist doesn't seem to be making a genuine appeal to Feuerstein and his viewers, the positioning of Feuerstein and his beliefs as illogical and doing so in a mocking way may have some positive effect on users who might be considering the weakness of the Christian faith in light of science. While there is clearly evidence of a core audience of like-minded individuals and an audience of users opposed to theamazingatheist's message, there is also potentially an audience of users who may be persuaded and for whom presenting a negative prototypical Christian might help convince.

Feuerstein is not the only object of derision, with commenters also taking aim at theamazingatheist on his own videos. Users write, for example:

science isn't on your side fat fuck, any scientist that has watched your video says "wow this guys a fucking retard i hope people aren't associating his fat ugly ass with science because that would make us look bad" look, if you wanna be butthurt about people 
believing in god, then leave it at that but don't ever talk about science because you don't know what the fuck you are talking about. you're not a scientist you're a fucking idiot. (2014.06.02 AA Video Comments)

The commenter takes issue with theamazingatheist's attempt to respond to the scientific inaccuracies in Feuerstein's video and challenges him aggressively for presenting himself as a kind of scientific expert. The commenter doesn't, however, appear to be affiliated with Feuerstein. Although Feuerstein's and theamazingatheist's arguments may suggest an "us" versus "them" mindset, the commenters do not always take such a simple approach. Here then, conflict is not limited to a simple storyline of Christians fighting with atheists. theamazingatheist's viewers and other atheists on YouTube do not simply take his side regardless of his position, an issue that is highlighted when he criticizes Feminism and receives criticism for his position from other atheists. While there may be a core of viewers that support him regardless of his position, atheists who oppose and ridicule him are also always present, something that isn't true of Feuerstein or John Fontain, the Muslim user.

The comment represents a larger difficulty with atheism as a category, where there is a tension between creating a community of atheism and atheists desiring independence in their individual disbelief (Cimino and Smith, 2011, 2014). While Feuerstein is, in many ways, an advocate for Christian belief, and his videos show his commitment to "spreading the gospel," theamazingatheist is not clearly advocating for atheism. When theamazingatheist does mention the atheist community, it is only to argue against people attempting to exclude him from it, something that he addresses in other videos. Rather than positioning himself as an advocate for or a leader of a community, he instead positions himself as a kind of antagonist, attacking people he finds to be ignorant or illogical, be they Christians, "social justice warriors," or feminists.

\subsection{Appealing and Consensus Building}

In contrast to his response to the atheist in Dear Mr. Atheist, the video Dear Mr. Muslim Feuerstein positions himself in a completely different way. Here he is not focusing on logic, but rather on the theological argument that Jesus was God. Like the video "Dear Mr. Atheist," the original posting of the video isn't available online but instead was re-uploaded by another user. John Fontain's response, Dear Joshua Feuerstein Muslim Response John Fontain was posted on June 1, 2014, suggesting that Feuerstein posted the original video around the same time as he posted his Dear Mr. Atheist video. From the beginning of the video, there is a clear departure from Dear Mr. Atheist in that Feuerstein does not engage "Mr. Muslim" from a point of defensiveness and 
does not present the video as a response to any attack. Instead, Feuerstein starts by praising his "Muslim friends," saying:
Mr. Muslim
now I must preface what I'm going to say by simply saying
that my Muslim friends are some of the most kind caring
compassionate
incredible individuals I have ever met
and to be quite honest with you
and sadly so
well your propensity towards prayer and
dedication to your religion
puts most Christians to shame

(Dear Mr. Muslim, JF Video) ${ }^{3}$

Feuerstein does not initially position himself as opposing Muslims. Instead, by praising the piety of his "Muslim Friends," the initial positioning suggests shared experience, particularly around the prayer and dedication to religion, something that Feuerstein says "puts most Christians to shame." The kindness to a potential Muslim audience suggests that Feuerstein might be making a genuine attempt to reach out to Muslims, although there is little evidence that he has a significant Muslim presence on his Facebook page. Moreover, Feuerstein does not continue in other videos to make an outreach to Muslims a significant part of his preaching. The video could then be seen as Feuerstein attempting to bat down attempts by Muslims to build shared alliances against atheism online, which is one of the reasons Feuerstein gives for Muslims reaching out to him.

Feuerstein goes on to describe why he is making this particular video addressing Muslims, saying,

and over the last week

I have gotten a couple hundred e-mails at least

from Muslims around the world that

have congratulated me

on the video I have recently made

and yet at the same time

they have questioned

well they have questioned my claim that Jesus Christ

is in fact the messiah

however it is in those questions that I find a couple of contradictions

how is it that Islam

says that Jesus Christ

is a prophet

${ }^{3}$ The transcript is taken from the re-uploaded version of the video. The original date of the video is not known. 
a mouthpiece of God

that he is a good man

and yet when I look at the words of Jesus Christ

well they seem to contra-

well they seem to contradict exactly what Islam says

you see Islam says that Jesus Christ was not the Son of God

that he was not

the savior of the world

that he was not the messiah

and yet when I look at what Christ claims

it's exactly that

for he says I am the way the truth and the life

and no man comes to the father

except

by

me

(Dear Mr. Muslim, JF Video)

The "video that I recently made" appears to be Feuerstein's Dear Mr. Atheist video in which he made an explicit argument for creationism, a belief shared with Muslims, and a video that Feuerstein claims has resulted in receiving "a couple hundred" emails. By mentioning the praise of Muslims, Feuerstein also suggests that others have positioned him as sharing a common belief about evolution. The positioning of Muslims and Christians as sharing belief is, however, quickly challenged around the issue of how Jesus should be treated. From an Evangelical Christian perspective, the claim that Jesus is a "prophet" or a "good man" rather than God is an important distinction between the faiths, one that separates Christianity and Islam from one another into noncompatible categories.

This way of talking about the relationship of Jesus to God and about the deity of Christ is not specific to Feuerstein's video to Muslims. It is part of a longer ongoing argument among Christians and Muslims since the beginning of engagement between the two faith traditions (Watt, 2013) and one that is highlighted in Christian missions to Islam in the contemporary world (Parshall, 2003). Feuerstein's argument, like his talk about evolution, suggests a misunderstanding of the theological position of Islam, particularly as it relates to belief about Jesus being the "Son of God." Indeed, as we will see in Fontain's response, what Feuerstein presents as problematic is not necessarily problematic for Muslims. Instead, it is the belief embedded in the statement "Jesus is the Son of God" which, for Feuerstein, means that Jesus is also God. While the text doesn't explicitly make this point, for Feuerstein, it appears obvious, something that anyone looking at the text should see.

This belief in the deity of Jesus Christ results from an interpretation that over time becomes embedded in the verse. The text then carries with it assumptions 
and beliefs, referred to as a "shared repertoire" in a community of practice (Lave and Wenger, 1991), in which texts can have a "richness" that denotes deeper beliefs. These beliefs are not necessarily explicit in talk among people holding the same deeper beliefs because they do not challenge one another. When making the same statement to a Muslim, however, where the belief is not shared, the video lays bare the implicit belief about the text. How the "shared repertoire" of language and belief affects interaction is highlighted in Feuerstein's emphasis on Jesus being "the only way" to the "Father," which revoices John 14:6, where Jesus is speaking to the disciple Thomas:

Thomas said to him, "Lord, we don't know where you are going, so how can we know the way?" Jesus answered, "I am the way and the truth and the life. No one comes to the Father except through me. If you really know me, you will know my Father as well. From now on, you do know him and have seen him." (John 14:5-7, New International Version)

In context, the passage is not clearly a statement about the exclusivity of Christian belief or faith in Jesus but is instead a metaphorical statement about how Jesus is the embodiment of the abstract concepts of the "way," "life," and "truth." However, in Christian apologetics, the passage takes on an important role in supporting the supremacy of Christ and Christian belief. That belief, however, is one that is built up from a specific set of interpretations of the Bible within a specific tradition. This context of belief is necessary for interpreting the scripture and providing a storyline with which Feuerstein can subsequently position others: that those who believe in Jesus can come to the Father and those who don't believe in Jesus cannot. For Feuerstein, however, if it is only necessary to assert the verse with the expectation that others will understand why he is quoting the verse. It is not a meaningful argument for Muslims because it doesn't seem to take into account any Muslim belief about the nature of Allah or Jesus in relation to God.

The use of scripture in this way also highlights a belief in the "common meaning" (Malley, 2004) of the Bible, that the message contained in the Bible is consistent and coherent across all the parts of the collected writings that make up the text and a belief that the Bible is the consistent and clear Word of God that is applicable in all situations (Bebbington, 1989). Christians on YouTube have been observed using different portions of the scripture to interpret other parts of the Bible (Pihlaja, 2013b, 2016b), a practice that Malley (2004) has also observed in the reading of the Bible in physical, local contexts. What readings count as legitimate or not favor certain second-order discourses (Foucault, 1981) that are viewed as authoritative for different groups. Feuerstein's use of the Bible to represent "what Jesus said" as authoritative, factual reporting highlights his own assumptions about the nature of the Bible and doesn't recognize different beliefs about the Bible that might be held by others, 
particularly Muslims who don't accept the authority of the text. By aligning himself with "what Jesus says," he positions himself as an authoritative figure.

This is highlighted in Fontain's response which makes clear that Feuerstein's reading of the passages is a particular interpretation. Fontain says, in response to Feuerstein's statement that Jesus is the way, the truth, and the life.

\author{
as a Muslim \\ we have no problem \\ it doesn't contradict Islam \\ Jesus is the way \\ the way we follow \\ Jesus is the truth \\ we believe he was truthful \\ he's the life \\ we have to follow him in this life \\ no one can get to him \\ no one can get to God \\ except through believing in him \\ no problem \\ it's your interpretation \\ that now \\ from \\ somehow from this verse \\ you're you're interpreting that Jesus is claiming divinity
}

(2014.06.01 JFo Video)

Fontain points out that the statement itself doesn't necessarily contain the claim that Feuerstein seems to present. By offering a second interpretation, Fontain problematizes the implicit argument in Feuerstein's video, which combines post-hoc beliefs about the scripture to interpretation. Fontain places the blame for the faulty argument solely on Feuerstein's "interpretation" of the Bible, highlighting that Feuerstein has taken the claim from a particular verse and extrapolated a larger theological point from it. Feuerstein, from Fontain's point of view, has taken a flawed English translation of the Bible and made assumptions about it, assumptions that are rooted not in truth or understanding of God, but in his own misconceptions.

Interpretation of the text does not, however, feature heavily in Feuerstein's talk either in his video targeting "Mr. Muslim" or in general. Indeed, the topic is almost entirely absent in Feuerstein's videos except when referring to it in a pejorative way: "You can't pick and choose what the Word of God says. The truth is not a democracy." Feuerstein presents "what God says" as clear and undisputed. His belief in the Bible downplays the role of interpretation and assumes, again, a "common meaning," one that true Christians and believers understand but non-Christians and non-believers cannot access. His lack of response to Fontain and his presentation in his initial video shows that the 
video is not, as he claims, intended as a way of addressing Muslims, but rather asserting a long-standing theological point to his Christian audience, without genuinely engaging with Muslim theology.

This point is made clearer as the video progresses. Feuerstein goes on to then refer to other parts of the Bible that also are used in apologetics to support the claim that Jesus is God, stating:

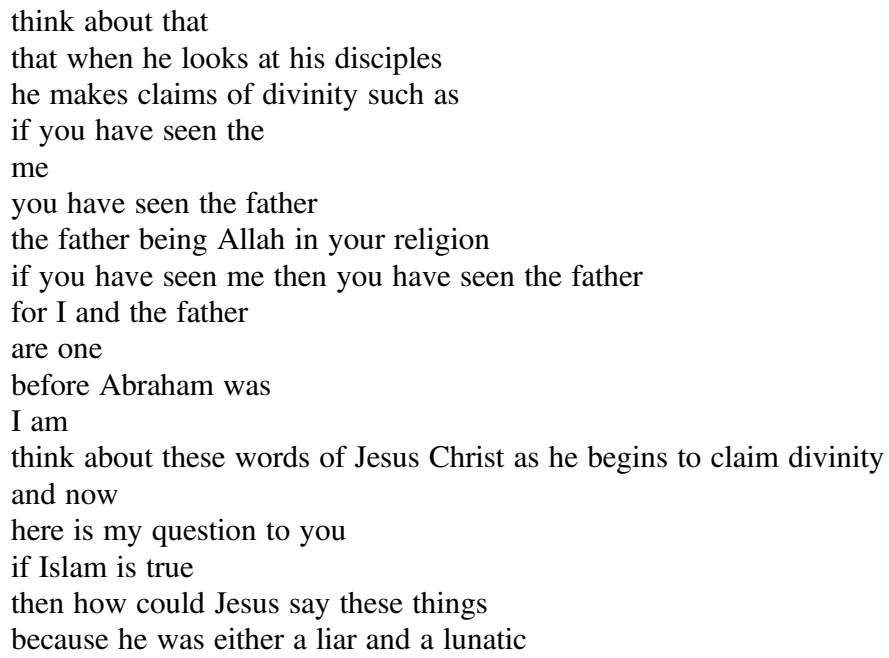

(Dear Mr. Muslim, JF Video)

Feuerstein's argument relies heavily on the supremacy of the Bible, and reporting on passages that, when taken together, might suggest that Jesus made a claim at divinity, particularly John 14:7 and John 8:56-58. Feuerstein presents these claims, however, as though they are facts without question and does not relate them at all to the source material, in this case taken from the Gospel of John. Feuerstein's conclusion to this argument, that Jesus must either be a "liar or a lunatic" is again a revoicing of a common Christian apologetic argument, originating in the 18th century (Hopkins, 1863) and popularized by the Christian writer and apologist C. S. Lewis (Lewis, 1952). By describing Jesus as either "was who he said he was" or a liar or lunatic, Feuerstein positions the audience in a storyline where an explicit choice must be made about Jesus. This storyline, however, is one that Muslims reject because of its assumption that the Bible clearly teaches that Jesus claimed to be God and the assumed authority of the Bible as reporting what Jesus actually taught.

As with the video on evolution, Feuerstein does little to address any actual arguments against the deity of Christ made by Muslims and instead repeats a gross simplification of the Muslim position, that Jesus was just a "good man" 
rather than God. He also does little to address the belief system of Islam, and challenge any particular beliefs that "Mr. Muslim" may hold. Instead, the argument follows the same pattern as his address of "Mr. Atheist," projecting a simplified argument on the person being positioned, and then presenting his own belief as a move to retain the "last word" as he did with theamazingatheist. The video does not ask any genuine questions of a Muslim audience or invite dialogue. Instead, it is presentation of Feuerstein's belief as it relates to Muslims, one that seems oriented toward an audience of believers who appreciate and understand the arguments to which he appeals.

Feuerstein goes on to repeat a simple description of Christian belief in the ending of his video, saying:

and so I propose to you
that Jesus Christ was the king of kings
the alpha the omega the beginning the end
the author and the finisher of our faith
the lion of the tribe of Judah
the lily of the valley
he was the beginning the end
he is everything in the middle
he is God
that is what I propose to you
and I propose to you that not only do I love you
but he loves you as well
and that he died on a cross for your sins
and shed his blood
for your sins

(Dear Mr. Muslim, JF Video)

Feuerstein's language falls into Evangelical Christian register, referring to Jesus in different ways taken from the Bible and which emphasize Jesus as a special figure, someone who is not simply "a good man." The response highlights key tenets of Christian belief about the death of Jesus on the cross as an act of propitiation, intended for the forgiveness of sins. At the center of the message is Feuerstein's focus on his "love" for the audience, one that mirrors the love of God. By positioning himself as acting out of love for others, Feuerstein can deflect criticism for any message he puts forward, even aggressive messages, because they are presented as being motivated by his own compassion. By stating his "love" for others, he can also implicitly position himself with God, as he does in this video. Feuerstein loves the viewer, and so does God.

The specific Christian register suggests that like his video aimed at atheists, he is actually addressing a Christian audience and presenting an apologetic case for the deity of Christ to other Christians rather than to a Muslim audience. Particularly by using phrases like "shed his blood for your sins," 
he is revoicing language from the Bible and taking its authority through quoting it. Users without an explicit knowledge of the Bible or Christian register would not find the phrases "the alpha and omega," "king of kings," "the lion of the tribe of Judah," or "the author and the finishers of our faith" to hold a particular reticent meaning. Instead, for viewers in the shared sociocultural context of Feuerstein, these phrases echo with the words of praise songs and sermons built up in shared experience. They are more than theological statements - the phrases have specific and important significance within the shared repertoire of American Evangelical Christian culture and are affective for a particular audience who share the same faith. Christian register may then serve as one way Feuerstein can deal with the context collapse in which a mixed audience of users are watching his videos. They mark him as a member of the Evangelical Christian community, complete with specific theological beliefs, and reflect important epistemologies about the nature of the world and how Feuerstein views himself. This belief can be recognized by users who understand the concepts behind the Christian register without Feuerstein explicitly having to state his belief. The theology is implicit in the way Feuerstein talks about himself and others in the world.

The video doesn't invite a response from Muslims. Instead, Feuerstein's approach is to present his belief to his audience and use analogy or an opposing position to highlight what he already believes. The video is decidedly a one-way message, with Feuerstein speaking out to an audience. There is no meaningful way "Mr. Muslim" could respond. Instead of an invitation, the video ends with a specific "challenge" to accept the Christian message:
so I challenge you today
to meet the Jesus that I know
the Jesus that will revolutionize you
the Jesus that will walk into your heart
and give you love compassion peace hope and joy
that is my prayer

(Dear Mr. Muslim, JF Video)

Feuerstein presents an invitation to Christianity to his "Muslim Friends," again using the language of Evangelical Christianity, one that focuses on Christ walking "into your heart," an important Christian metaphor for a "relationship" with God, another difference between Christianity and Islam that is highlighted in "outreach" to Muslims by Christians (Parshall, 2003). Feuerstein positions himself as offering something different and better to the Muslim audience, one that will "revolutionize" them. Like Dear Mr. Atheist, the message focuses on the experience of individuals and coming to know Jesus within their "hearts." The language of the "challenge" suggests that despite Feuerstein's positive 
positioning of "Mr. Muslim" at the outset, Feuerstein implicitly suggests that Muslims should become Christians, a positioning fits into a larger storyline that Christians believing in Jesus come to know God, while Muslims do not. It encourages and reinforces the belief Feuerstein's Christian audience would already hold about Muslims and Islam. Although Feuerstein does implicitly challenge the validity of Islam as a path to God, he doesn't directly confront a Muslim user. Instead, he very carefully "proposes" a statement to the audience, without making any demands. Like many of Feuerstein's calls to action, he makes a suggestion and "challenges" people to change their behavior. This tactic contrasts with a more heavy-handed approach that might state explicitly that Muslims should become Christians. There is also little recognition of what Muslims might already believe or an attempt to bridge the gap between the two faiths. The call to faith further supports an argument that Feuerstein is using his social media platform to primarily encourage like-minded users and to reach out to users who already have a shared cultural understanding that may allow them to understand the message of "salvation" as he has presented it.

The video did result in a response from the Muslim user, John Fontain, who like Feuerstein did not generally respond to other users specifically on his YouTube channel prior to this video. His response, however, Dear Joshua Feuerstein Muslim Response John Fontain, is a direct message to Feuerstein, one that is carefully produced with Fontain replaying key parts of Feuerstein's video in a carefully edited response. Fontain begins the video with a playful parody, wearing a backward baseball cap, saying, "Welcome to video" and then:

I'm not racist against Americans

you know

I have many American friends

I don't mind Christians

I used to be one

(2014.06.01 JFo Video)

Fontain's short parody of Feuerstein is markedly less aggressive and negative than theamazingatheist, highlighting Fontain's softer, more conciliatory approach to the presentation of his faith. The video is not about attacking Feuerstein, but looking for common ground between the two, something that is a recurring theme in his videos overall, particularly as his message relates to Christians. While theamazingatheist mocked Feuerstein, Fontain positions himself in a much more friendly way, playing Feuerstein's quote from the Dear Mr. Atheist video that "Evolution is not a science; never has and never will be" and giving a smiling thumbs up without saying anything. Like Feuerstein, the presentation of the words and beliefs of the other is first shown 
in a way of affiliation, both of which are implicitly critical of evolution, and by extension, atheism. These moments within both Feuerstein's and Fontain's videos attest to the importance of considering how discourse builds as an event. The affiliation in not consistent throughout the video, but it plays an important role in what follows and how viewers understand the position of the content creator in relation to them.

Like Feuerstein, the initial positioning is key to what follows in the video. Christians and Muslims are starting from the same place and despite what differences they might have, there is shared common ground in their belief. This is the beginning of a storyline in which Islam is a more consistent and truthful depiction of what Christians already believe, a storyline that appears in other videos in which Fontain speaks to Christians while doing "street dawah." In one video, Fontain is speaking with a Christian woman and says to her, when she agrees with him that there is only one God, "You are Muslim. Your beliefs are Muslim. They are not Christian." For Fontain, the distance between Christianity and Islam is not as significant as Feuerstein has presented. Fontain does make the important theological distinction that believing Jesus is God is a mistake. However, instead of mocking or attacking them, he presents Christians as simply misguided and much closer to Islamic belief than they might initially think. Fontain, responding to Feuerstein's claim that Jesus is "the way, the truth, and the life," says,

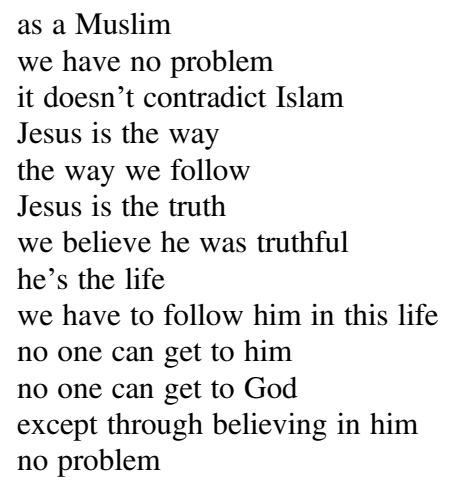

(2014.06.01 JFo Video)

Unlike Feuerstein who makes a simple concession to Muslim belief and then moves on to positioning Christianity as different from Islam, Fontain's tactic is the opposite, using the majority of his video to position himself and his belief as the same as Christians. Fontain positions his belief in Jesus as "the way," accepting what Feuerstein has presented as a key tenet of the Christian belief. By aligning himself with the statement that "No one can get to God except through believing in [Jesus]," Fontain positions himself and Feuerstein and 
Feuerstein's audience in the same way, as followers of Jesus moving toward God. In this storyline, there is no difference between Christians and Muslims they both believe and want the same thing.

Positioning himself in this way, as affiliated and in agreement with Christians, is a recurring theme in Fontain's videos, showing that Christian belief and Islam are not in conflict with one another. Fontain regularly refers to a dawah book that he has published called Jesus and the Injeel which argues that Jesus, in his ministry was actually preaching the "injeel" which is mistranslated at "gospel" in the Bible and actually refers to a revelation from God to Jesus as a prophet, similar to the message given to other prophets. The argument attempts to deconstruct the Bible as an authoritative source and suggest that Jesus preached the same message from Allah as preached by other prophets. Instead, the argument holds, the message was consistently misinterpreted throughout the years, leading to the Bible being an inconsistent record of "God's word." While the argument positions the Bible in a negative way, importantly, it does not reject Jesus as "the way, the truth, and the life." Fontain asks users to share his video including the point that the "injeel" presented to Jesus is one of the five proofs of Islam, saying, "Share the video. Share the knowledge and convey this new point of evidence in a brotherly way to our cousins in faith." By positioning Christians as "cousins" to Muslims, Fontain makes clear that the message he is spreading is not inconsistent with the dominant belief of Christianity.

Finally, Fontain turns Feuerstein's argument against the atheists against Feuerstein, and he challenges Feuerstein's claim that Jesus is God saying,

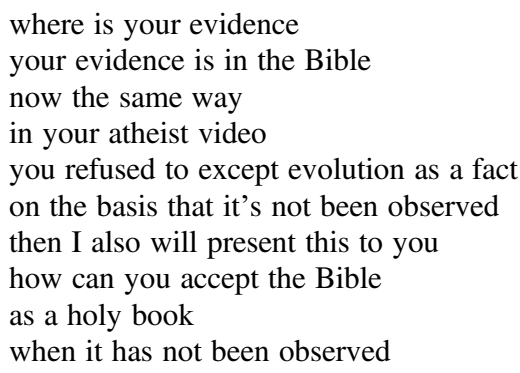

(2014.06.01 JFo Video)

Although Feuerstein had focused his criticism on the belief that Jesus is not God, he presented what he believed to be authoritative evidence: the Bible's words as he presented them. For Fontain, this evidence is not sufficient, and he asks and answers the rhetorical question "Where's your evidence?" challenging the Bible in the same way that Feuerstein has challenged evolution in his video aimed at atheists, by claiming that the Bible as a "holy book" has never been observed. Like Feuerstein's criticism of Islam and the assertion of the 
deity of Christ, Fontain's challenge of the Bible as an authoritative text is also a recurring theme in Christian-Muslim debates (Watt, 2013) and one that, in my observations, features regularly in discussions among Christians and Muslims on YouTube. For Fontain, questioning the Bible as an "observed" holy book implicitly challenges it as an authority.

Like Feuerstein's positioning of atheists as illogical, Fontain's challenge of Feuerstein makes an appeal to logic and evidence. It also suggests that Feuerstein is being inconsistent in his belief by rejecting evolution based on its lack of evidence but not applying the same criteria to the Bible. Fontain doesn't challenge the Bible explicitly or state that it is inconsistent, but he positions himself as questioning and asks Feuerstein to produce evidence in support of his claims. The argument puts the onus on Feuerstein to produce further evidence in support of the Bible. Fontain's challenge back to Feuerstein and the lack of a response suggests that Feuerstein is actually uninterested in dialogue with a Muslim audience. Although Feuerstein engages in apologetic arguments from time to time, the way he uses his social media presence does not favor having a long, measured discussion of the validity of the Bible.

Although Feuerstein and theamazingatheist appeared to target specific audiences, Fontain's audience is less clear. In 2014, he was a relatively new YouTuber using the site to promote his book. The approach to Feuerstein in the video suggests that Fontain, more than Feuerstein and theamazingatheist, is appealing to a third audience beyond those who share the same belief system. With the challenges on Christian religion being specifically focused on the lack of logic and intelligence, Fontain's presentation here and elsewhere of the logic of Islam and the consistency of the Qur'an in contrast to the Bible appeals to an audience beyond Christians and Muslims. By positioning himself as a free thinker and truth seeker, Fontain aligns himself with the atheists attacking Feuerstein. However, many of Fontain's interactions are with Christians, which he shows in his street dawah videos. While Feuerstein uses social media to present his own message without response and theamazingatheist uses response as a way of producing entertaining content, among the three users, Fontain seems the most interested in dialogue with whom he disagrees. In his videos showing himself doing street dawah in a variety of situations, this same positioning of himself as seeking truth and eager to engage in meaningful conversation is a recurring theme, with a storyline that positions all humans as seeking truth and understanding, and on the same path to knowledge of truth as it is presented in Islam.

While Feuerstein did not respond to Fontain, arguments in the comments show that Fontain's video attracted interest from Christians, Muslims, and atheists, all eager to argue different aspects of Fontain's claims. The comments show that there is indeed a diverse group of viewers engaging Fontain's content, including the diversity of issues that appear in this video. The longest 
thread of conversation includes a Christian questioning the authority of the Qur'an and a reasoned argument about specific claims with it, with polite comments from both sides including from a Christian responding to a Muslim: "Thank you for clearing that up [NAME]." and a Muslim responding to a Christian, "Hey [NAME]! I respect your thoughts and am going to adress all your points God willing." The discussion follows a genuinely positive path, although no users appear to change their minds.

However, despite these positive comment threads and Fontain's focus on Feuerstein's argument about similarities between Christians and Muslims, the comment receiving the most thumbs up (at 95), states: "Islam is the most dangerous religion today." This leads to an extended argument and a relatively reasonable discussion about the role of religion in inspiring violence, despite not occurring in the video. Unlike Feuerstein and theamazingatheist's videos, the larger sociopolitical context of Islam in the West appears to play a role in how the arguments develop and what topics are addressed by the users. The comments on the video also show the limitations that Fontain faces in presenting Islam in a social media context where users are often antagonistic toward religion generally, and quick to discuss the role of religion, and particularly Islam, in the propagation of violence. While the video focuses on positioning Christians and Muslims together, the comments suggest that the effect of this positioning is limited. Users push back against the notion of religion, generally, with users writing, for example, "All religions are rubbish built from fear and ignorance" and "Hey Joshua and John; fuck you; your both retards; you BELieve in the adult version of Santa Claus!' Fontain's interest in appealing to Feuerstein and affiliating with Christian belief provides an affordance for users to reject both religions together as equally illogical.

Users, when responding to each other in videos, are always positioning themselves in relationship to their audience. Who might be included in that audience is complicated by popularity and users' nominal roles as leaders in their different communities. This doesn't mean, however, that users are unaware of to whom they're speaking - Litt, and Litt and Hargittai (2012; 2016) have worked with Goffman's notion of the "imagined audience" to investigate how users think about audience when posting on social media, concluding that users are actually quite aware of their audiences. Litt and Hargattai (2016) write, "Even though users often interacted with large, diverse, and invisible audiences, they coped with the audience challenges by thinking about a general abstract audience or by thinking about a more targeted audience as they posted" (p. 9). Despite the context collapse of social media, users can and do cultivate specific audiences for specific content.

Feuerstein, Fontain, and theamazingatheist do this discursively, appealing to particular audiences through the way they talk about themselves and others. Limiting one's audience isn't, of course, always possible and users can't 
control who watches their videos. Cameron (2015) writes that "every aspect of a situation that we investigate and theorize is connected to other aspects of the situation" (p. 9). How these connections emerge on different scales, with different aspects of the interaction affecting the outcomes is highlighted in these two cases of conflict, one which marked by antagonism and another which is marked by a much more conciliatory tone. Clearly, painting any sort of description of "religious talk online" with broad strokes is unwise. At the same time, the patterns for interaction that we have observed have precedence in arguments about theology and religion more generally, be they patterns for representing evolution or discussions about the deity of Christ. The positions that users take and respond to are both specific to the local context and part of larger storylines about themselves and others.

What is common in the interactions is how users respond to others and present their own beliefs as responses to the beliefs of others, assuming a discursive relationship. This relationship goes beyond a dialogue, real or imagined, with other users. It also includes an ongoing conversation with the audience, with the content producers positioning themselves in an authoritative way, and viewers affirming the positioning explicitly in their comments and implicitly in viewing, "liking," or sharing the video. This affects not only the presentation of beliefs, but also the potential development of communities around users, who become spokespeople for particular beliefs. At the same time, little of this seems to be based on explicit appeals to identity-based communities. Instead, users are more likely to make individual arguments and avoid language that explicitly positions "we" against "them." Rather, users assert their position as correct and make an invitation for others to agree with them.

Discussion of religious topics initiates opposition and creates an environment where user response to the messages of others results in opportunities for content creation, a historical feature of argumentation (Billig, 1996). This content can be the basis for building affiliation among users, who find the videos and agree with the position taken by the content creator. Unlike echurches or other online religious communities where shared belief is the starting point of the community (Hutchings, 2007; Estes, 2009), the videos we've so far examined are built in part on the back-and-forth of argumentation and the actions of others without a direct appeal to users coming together in any way behind a particular idea or belief. As a complex, dynamic system, unexpected components and influences can spur change, reflected in language use as users react to specific, disparate audiences (Androutsopoulos, 2014). The affiliation of Muslims and Christians in a shared distrust for evolution serves as a good example of this, one that appears to be unexpected for users in the data set, including Feuerstein. The result is a new series of affordances, providing further opportunities to present one's beliefs. 


\subsection{Conclusion}

In the videos, conflict and antagonism have different effects, particularly when users are engaged in arguments with others who may not share the same beliefs as them. Conflict provides an affordance for users to present their own beliefs and build support, by positioning themselves as being attacked by others. Feuerstein's positioning as a religious and moral authority includes a positioning of Muslims and atheists as illogical, providing chances for new positionings to emerge in responses. These include positioning Feuerstein as either ignorant (by the theamazingatheist) or as misguided and unenlightened (by John Fontain). Through opposition and attempts made to silence other users, responses allow for the development of new positions in the changing social context. They respond to positionings and are subsequently given the opportunity to challenge the positioning with a new one. Social media interaction can then benefit from conflict, regardless of how negative it might be, as it gives content producers a platform to broaden their audience and reevaluate and remake previous positionings. At the same time, the constant conflict can lead to users taking more entrenched positions that are much less hospitable as the arguments continue. The following chapter will look more closely at how users position themselves with larger storylines to make sense of the conflict. 